
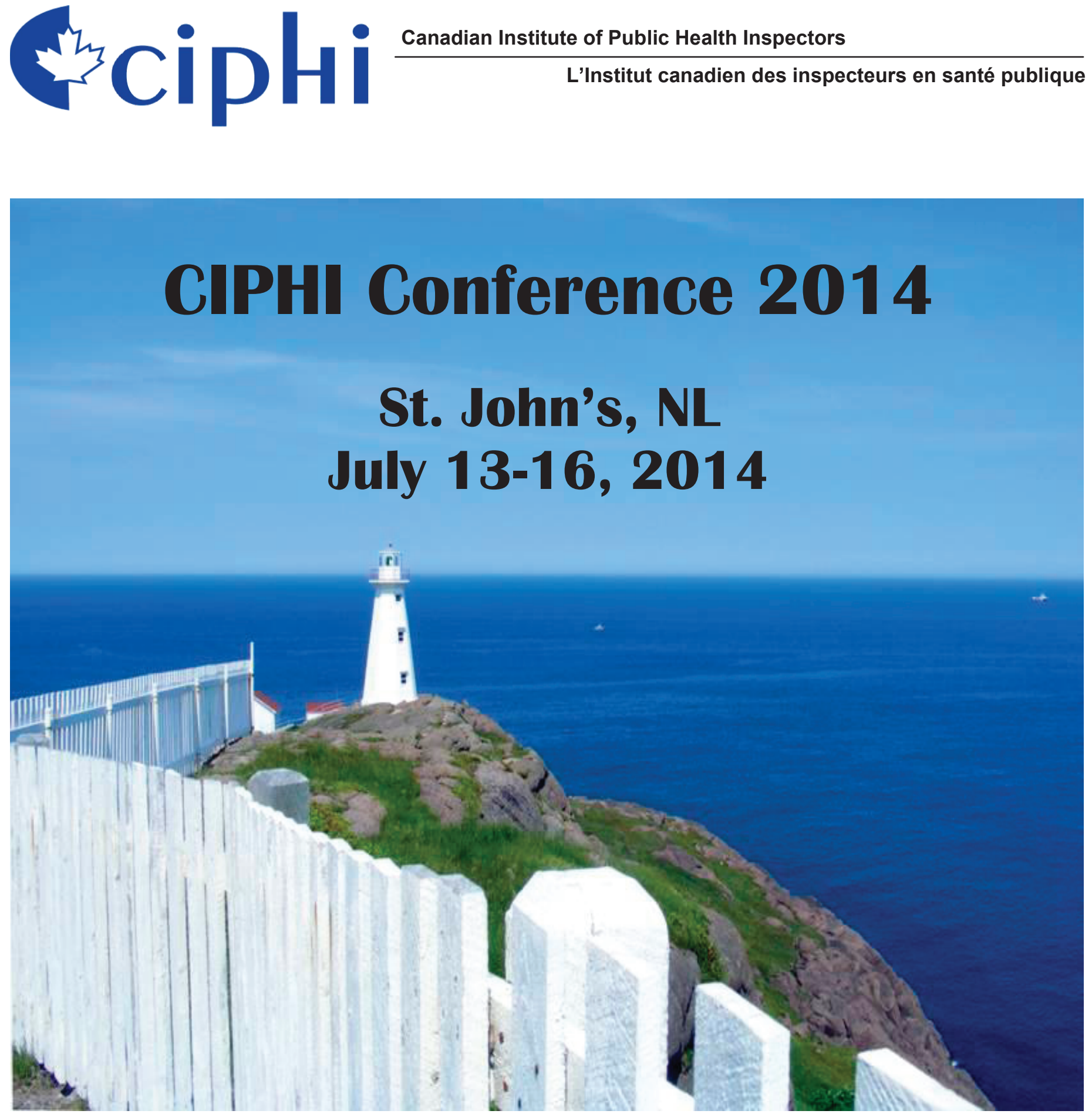

Photo Credit: Kelli Smith, Environmental Health Officer, NL Branch

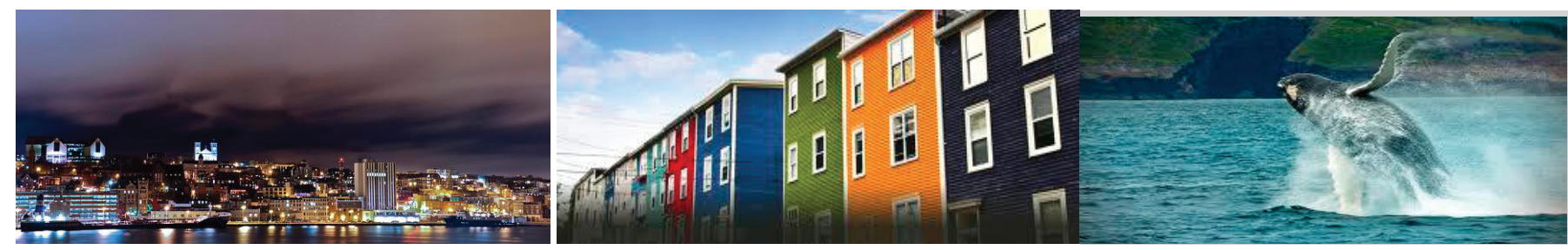




\section{Educational Program}

The conference committee is working towards finalizing the roster of keynote speakers for the 2014 conference. A keynote speaker will address conference delegates each morning prior to the start of the day's educational program. Delegates can expect to be inspired and informed about the future of public health, environmental health and our profession.

The conference will feature a triple stream of professional concurrent sessions focusing on children's environmental health, human health and climate change, emerging threats to human health, air quality, food safety and drinking water contamination.

Given that the European Commission launched Health for Growth program and the World Health Organization and is wrapping up their final year of the Millennium Development Goal (MDG 7) on environmental sustainability to "halve by 2015 the proportion of people without sustainable access to safe drinking water and basic sanitation", we will host one of the three tracks to feature presentations on global environmental health issues for the upcoming years.

A call for abstracts for the conference committee encourages you to consider presenting at the 2014 conference. For information on submitting an abstract please visit the conference website at www.ciphi.nl.ca

\section{Hotel Information}

The 2014 Conference will be held at the St. John's Sheraton Hotel and Conference Centre, just steps away from the historic downtown core of the city. A block of rooms has been reserved for conference delegates with rates beginning at $\$ 185$ (plus taxes). To reserve your room at this reduced rate, go to http://www.starwoodhotels.com/ sheraton/property/overview/index.html?propertyID $=3455$ or reservation code $\mathrm{CPG} 11 \mathrm{G}$ or follow the hotel link on the registration page of our website at www.ciphi.nl.ca

\section{Conference Sponsorship}

Sponsorship and/or having a booth in our exhibit hall will provide exposure to your product or service to EPH professionals and managers in a position to make purchasing decisions for their organizations. In addition, EPH professionals who are knowledgeable about what tools are available to the facilities they inspect will be able to provide accurate information to the business owners. Review the sponsorship categories available and consider also reserving a prime location in the exhibit hall. Don't be left out of this premier national conference! Visit the conference website at www.ciphi.nl.ca to view the sponsorship/exhibitor prospectus and contract.

\section{Social Programs}

Sunday July 13, 2014 - Boat Tour (tentatively mid-morning and afternoon)

Sunday July 13, 2014 - Welcome Reception (7-10)

Monday July 14, 2014 - Network Luncheon and Rally in the Alley (evening)

Tuesday July 15, 2014 - Lunch in Downtown St. John's and President's Banquet (evening)

Wednesday July 16, 2014 - Awards Luncheon (optional excursions available in the afternoon)

Go to www.mccarthysparty.com or visit the conference hospitality desk to register 


\section{Registration Form}

Canadian Institute of Public Health Inspectors $80^{\text {th }}$ Annual Educational Conference

July 13-16, 2014

Sheraton Hotel and Conference Centre

St. John's, Newfoundland and Labrador, Canada

\section{Conference Delegate Information}

Delegate's Name:

$\square$ Check here if you wish to have your name included in the published list of conference delegates.

Title/Position:

Organization:

Address:

City: Province:

Postal Code: Phone Number:

Fax: E-mail:

Name on Delegate Tag (First Name Only):

Special Dietary/Mobility Requirements:

\section{Method of Payment}

Cheque or $\square$ Money Order Payable to CIPHI Conference 2014 Credit Card Payment:

$\square$ Visa $\square$ MasterCard $\square$ American Express Card \#:

Expiry Date (mmyy):

Cardholder's Name:

Written requests for cancellation must be received by May 1, 2014 by the Conference Chair through the mail or fax to receive a full refund (less $20 \%$ processing fee). No refunds will be given following this date. Substitutions (alternates) are permitted up to and including the first day of the conference.

Note:
Credit card charges will appear as McCarthy's Party on your credit card statement.

\begin{tabular}{|c|c|c|c|}
\hline Registration Fees (CDN Funds) & $\begin{array}{l}\text { CIPHI/NEHA } \\
(+13 \% H S T)\end{array}$ & $\begin{array}{l}\text { Non-Member } \\
(+13 \% H S T)\end{array}$ & Amount \\
\hline$\square$ Early Bird Full Registration* ( By May 31, 2014) & $\$ 575$ & $\$ 650$ & \\
\hline$\square$ Full Registration (After May 31, 2014) & $\$ 599$ & $\$ 675$ & \\
\hline Daily Registration** $\square$ Monday $\square$ Tuesday $\square$ Wednesday & $\$ 199$ & $\$ 215$ & \\
\hline$\square$ Student/Retired Member Full Registration & $\$ 150$ & $\$ 215$ & \\
\hline Student/Retired Daily Registration $\square$ Monday $\square$ Tuesday $\square$ Wednesday & $\$ 75$ & $\$ 90$ & \\
\hline \multicolumn{2}{|c|}{ Social Events (cost for additional tickets $+13 \%$ HST) -boat tour is not included in full registration } & \# of Tickets & \\
\hline$\square$ Boat Tour (Sunday, July 13, 2014) - not included in registration & $\$ 50$ & & \\
\hline$\square$ Welcome Reception (Sunday, July 13, 2014) & $\$ 30$ & & \\
\hline$\square$ Network Luncheon (Monday, July 14, 2014) & $\$ 35$ & & \\
\hline$\square$ Rally in the Alley (Monday, July 14, 2014) & $\$ 80$ & & \\
\hline$\square$ President's Banquet (Tuesday, July 15, 2014) & $\$ 80$ & & \\
\hline \multirow[t]{2}{*}{$\square$ Awards Luncheon (Wednesday, July 16, 2014) } & $\$ 40$ & & \\
\hline & & Total(CDN\$) & \\
\hline
\end{tabular}

Registration: Send form by fax to 1.709.579.1000; print and return with payment to CIPHI Conference 2014 c/o McCarthy's Party, 566 Water St., St. John's, NL, Canada, A1E 1B8; or visit www.mccarthysparty.com to register online.

*Full registration includes the following: Welcome Reception, Network Luncheon, Rally in the Alley, President's Banquet and Awards Luncheon. ${ }^{* *}$ Daily registration includes that day's nutrition breaks and lunch (Tuesday lunch is on your own). Evening social events are not included.

${ }^{* * * N E H A ~ m e m b e r s h i p ~ r e g i s t r a t i o n ~ b e n e f i t s ~ a p p l y ~ t o ~ U n i t e d ~ S t a t e s ~ r e s i d e n t s ~ o n l y . ~}$ 